\title{
PRODUKTIVITAS TENAGA KERJA INDUSTRI PENGOLAHAN TEMBAKAU PADA PT INDONESIAN TOBACCO Tbk. KOTA MALANG
}

\author{
Irma Yoshida Rahman, Wahyu Hidayat Riyanto, M. Sri Wahyudi S \\ Program Studi Ekonomi Pembangunan, Fkaultas Eknomi dan Bisnis, Universitas Muhammadiyah \\ Malang, J1.Raya Tlogomas No.246 Malang, Indonesia \\ * Corresponding author: irmayoshidaa13@gmail.com
}

\begin{tabular}{|c|c|}
\hline Artikel Info & Abstract \\
\hline Article history: & Small and medium industries are industries that have the \\
\hline Received 25 November 2019 & greatest potential anywhere, one of which is the tobacco \\
\hline Revised 5 December 2019 & processing industry in Malang. This industry has many \\
\hline Accepted 10 January 2020 & positive impacts on society. This is because it can provide a \\
\hline Available online 15 February & large influence on the region, such as building job availability \\
\hline 2020 & and can improve the local economy of the community itself. \\
\hline & The purpose of this study was to analyze the level of \\
\hline Keyword: Labor Productivity; & productivity of the tobacco processing industry workforce at \\
\hline Education Level; Wages; Age. & $\begin{array}{l}\text { PT Indonesian Tobacco Tbk. Malang City, analyzed the } \\
\text { level of education, wages, and age of labor productivity of the }\end{array}$ \\
\hline JEL Classification & tobacco processing industry at PT Indonesian Tobacco Tbk. \\
\hline $\mathrm{C} 31, \mathrm{E} 24, \mathrm{~N} 3$ & $\begin{array}{l}\text { Malang city. This study uses primary data with } \\
\text { questionnaire data collection methods. The analytical tool } \\
\text { used is multiple linear regression with cross-section data } \\
\text { models. The results showed that the coefficient of } \\
\text { determination obtained by } 0.982 \text {, which means that } 98.2 \\
\text { percent of changes in labor productivity is influenced by } \\
\text { variables of education level, wages, and age, while } 1.8 \text { percent } \\
\text { is caused by other factors not included in the regression } \\
\text { equation. }\end{array}$ \\
\hline
\end{tabular}

\section{PENDAHULUAN}

Suatu pembangunan merupakan upaya dalam mencapai kesejahteraan sosial (Arsyad, 2003). Dengan melakukan kegiatan yang dilakukan untuk mengembangkan kegiatan ekonomi. Adanya pembangunan dikatakan berhasil apabila dapat memiliki kualitas penduduk yang memadai dan dapat mendorong pertumbuhan ekonomi. Salah satu tujuan pembangunan ekonomi yaitu penyediaan lapangan pekerjaan sehingga menghasilkan suatu tenaga kerja yang dapat meningkatkan pertumbuhan angkatan kerja. Hal ini dapat diketahui bahwa untuk meningkatkan ketenagakerjaan dengan membuka peluang pada sektor industri kecil. Saat ini sektor industri kecil merupakan sektor industri dalam jumlah yang banyak di Indonesia, salah satunya yaitu

industri pengolahan tembakau yang ada di Kota Malang. Untuk industri ini dapat memberikan peluang bagi masyarakat khususnya Kota Malang, dengan menambah lapangan pekerjaan sehingga akan dapat meningkatkan perkeonomian daerah tersebut. Industri pengolahan tembakau di Kota Malang salah satu industri yang masih tergerak dalam sektor perindustrian. Dengan hal ini dapat mengetahui bagaimana produktivitas tenaga kerja industri pengolahan tembakau yang ada di Kota Malang. Namun untuk saat ini menurut survey BPS (Badan Pusat Statistik) mengatakan bahwa perkembangan kondisi industri kecil pengolahan tembakau dalam keadaan kurang baik dan mengalami penurunan hingga 20,45\%. Dalam kurun waktu 6 


\section{Produktivitas Tenaga Kerja Industri Pengolahan Tembakau Pada Pt Indonesian Tobacco Tbk. Kota Malang

tahun jumlah perusahaan industri pengolahan tembakau mengalami penurunan sebanyak 463 perusahaan. Hal ini dikarenakan adanya beberapa faktor yaitu musim panen tembakau sedang mengalami penurunan produksi, kenaikan tarif cukai dari tahun ke tahun, minimnya perhatian pemerintah hingga persoalan stigmatisasi pihak kesehatan terhadap produk hasil tembakau. Adanya permasalahan ini akan berdampak terhadap ketenagakerjaan dari penurunan jumlah industri hasil tembakau di Kota Malang, sehingga menurut data pada tahun 2015 sebanyak 2000 tenaga kerja kehilangan pekerjaannya. Meskipun kondisi industri pengolahan tembakau saat ini sedang mengalami penurunan, kebutuhan konsumsi rokok dari tahun ke tahun terus meningkat. Berdasarkan data Kementrian Perindustrian, pertumbuhan produksi rokok naik berkisar 5\% hingga 7,4\% per tahun. Pada tahun 2015 Kemperin memprediksi produksi mencapai 398,6 miliar batang, tahun 2016 sekitar 5,7\% yakni menjadi 421,1 miliar batang, dan pada tahun 2020 diproyeksikan mencapai 524,2 miliar batang. Dengan demikian dapar diartikan bahwa masih banyak tembakau yang dibutuhkan sebagai bahan baku industri.

Terdapat beberapa penelitian terdahulu yang meneliti mengenai produktivitas tenaga kerja, yaitu penelitian Tambunan, (2012) berdasarkan penelitiannya mengatakan bahwa variabel pendidikan bertanda negatif tetapi tidak signifikan yang berarti pendidikan tidak memiliki pengaruh terhadap produktivitas tenaga kerja. Namun lain halnya dengan variabel pendidikan bahwa variabel upah merupakan variabel yang berpengaruh positif dan merupakan variabel yang paling dominan terhadap produktivitas tenaga kerja. Adhadika, (2013) berdasarkan penelitannya mengatakan bahwa variabel pendidikan, upah, insentif, dan pengalaman kerja berpengaruh positif dan signifikan terhadap produktivitas tenaga kerja, sementara variabel jaminan sosial tidak memiliki pengaruh yang signifikan terhadap produktivitas tenaga kerja. Herawati, (2013) berdasarkan penelitiannya mengatakan bahwa variabel upah, pengalaman kerja, jenis kelamin, dan umur berpengaruh siginifikan terhadap produktivitas tenaga kerja industri shuttlecock. Sedangkan variabel pendidikan tidak berpengaruh secara signifikan terhadap produktivitas tenaga kerja industri shuttlecock di Kota Tegal.

Adapun penelitian lain yang telah dilakukan mengenai produktivitas tenaga kerja yaitu penelitian Maria, (2012) menyatakan bahwa penelitian ini variabel upah dan variabel insentif berpengaruh signifikan terhadap produktivitas tenaga kerja, tetapi untuk variabel pemdidikan dan variabel jaminan sosial tidak berpengaruh terhadap produktivitas tenaga kerja. Putri, (2017) menyatakan bahwa penelitian ini variabel kesehatan, variabel pendidikan, dan variabel upah secara bersama-sama memiliki pengaruh yang signifikan terhadap produktivitas tenaga kerja. Namun variabel kesehatan memiliki pengaruh yang secara signifikan terhadap produktivitas tenaga kerja, sedangkan variabel pendidikan dan variabel upah secara parsial tidak berpengaruh signifikan teradap produktivitas tenaga kerja. Djunaedi, (2009) menyatakan bahwa penelitian ini perluasan kesempatan kerja belum merata diseluruh sektor. Untuk sektor pertanian meskipun penyerapan tenaga kerjanya tinggi namun dari tahun ke tahun produktivitasnya cenderung 
menurun. Demikian pula untuk sektor angkutan, jasa dan perdagangan yang juga mengalami penurunan produktivitas tiap tahunnya. Untuk sektor listrik mengalami perkembangan produktivitasnya tinggi atau mengalami tren yang positif. Rahman, (2016) menyatakan bahwa secara serentak investasi, pengeluaran pemerintah dan tenaga kerja berpengaruh positif dan signifikan terhadap Produk Domestik Regional Bruto dengan hasil uji F statistik lebih besar dari $F$ tabel. Sedangkan uji parsial menunjukkan bahwa investasi dan pengeluaran pemerintah berpengaruh positif dan signifikan sedangkan tenaga kerja berpengaruh negatif terhadap Produk Domestik Regional Bruto. Tomasowa, (2011) menyatakan bahwa alat analisis yang digunakan yaitu Loqation Quotient (LQ), tenaga kerja produktivitas, elastisitas tenaga kerja, MRP, dan tipologi klassen. Dengan hasil penelitian yang menunjukkan bahwa keuangan, sewa gedung dan sektor perusahaan jasa, merupakan sektor unggulan dalam menyerap tenaga kerja. Hidayatullah, (2013) menyatakan bahwa alat analisis yang digunakan yaitu analisa regresi linear dengan menunjukkan koefisien regresi adanya pengaruh tenaga kerja dan modal terhadap produksi batik per bulan. Variabel produksi batik bulanan dipengaruhi oleh faktor dari sejumlah tenaga kerja dan modal, sementara sisanya ditentukan oleh faktor lain dari variabel yang diteliti. Sulistyono, (2011) menyatakan bahwa terdapat faktor yang mempengaruhi mobilitas tenaga kerja yaitu usia, tingkat pendidikan, pendapatan (upah) yang diterima, dan jumlah tanggungan keluarga. Diketahui arah mobilitas tenaga kerja didominasi sektor perdagangan. Berdasarkan hasil penelitiannya, maka implikasi penelitian ini adalah perlu adanya peningkatan dalam kualitas sumber daya manusia secara sektoral, pendidikan dan keahlian dalam masyarakat, serta pemerataan arah mobilitas sehingga timbul keselarasan dalam pembangunan.

Berdasarkan penelitian yang telah dilakukan sebelumnya mengenai produktivitas tenaga kerja yang ada di Indonesia dengan beberapa variabel yang digunakan adapun hal yang membedakan penelitian ini dengan penelitian sebelumnya yaitu berdasarkan pada tahun penelitian, wilayah penelitian, dan variabel yang digunakan. Penelitian ini bertujuan untuk menganalisis produktivitas tenaga kerja pada industri pengolahan tembakau pada PT Indonesian Tobacco Tbk. Kota Malang. Dalam penelitian ini yang digunakan hanya beberapa variabel yaitu tingkat pendidikan, upah, dan umur yang berbeda dengan penelitian lain serta wilayah yang diteliti. Sehingga penelitian ini dapat memberikan acuan atau hasil yang berbeda dari penelitian lain untuk mengetahui seberapa besarkah produktivitas tenaga kerja industri pengolahan tembakau Kota Malang, apakah berpengaruh besar atau tidak.

\section{METODE PENELITIAN}

Dalam penelitian ini terdapat beberapa variabel yaitu tingkat pendidikan, upah, dan umur. Dari ketiga variabel tersebut akan dihitung dari industri pengolahan tembakau tersebut, dimana pada hasil akhir akan diketahui apakah berpengaruh besar terhadap produktivitas tenaga kerja industri pengolahan tembakau Kota Malang.

Populasi dan Sampel 
Dalam penelitian ini yang menjadi populasi adalah seluruh tenaga kerja bagian produksi industri pengolahan tembakau PT Indonesian Tobacco Tbk. Kota Malang yang berjumlah 370 orang. Dengan sampel yang digunakan yaitu $10 \%$ dari jumlah populasi $370 \times 100 \%=37$ orang industri pengolahan tembakau PT Indonesian Tobacco Tbk. Kota Malang.

\section{Teknik Pengumpulan Data}

Penelitian ini menggunakan 3 teknik untuk pengumpulan data yaitu teknik kuisioner, teknik wawancara, dan dokumentasi. Untuk teknik kuisioner yaitu dengan membuat daftar pertanyaan yang akan diberikan kepada karyawan (responden). Kemudian untuk teknik wawancara yaitu dengan bertanya langsung kepada karyawan industri pengolahan tembakau. Dan untuk teknik dokumentasi yaitu dengan memperoleh dari sumbersumber yang berhubungan dengan penlitian ini.

\section{Analisis Data}

Penelitian ini menggunakan 4 analisis data yaitu analisis regresi linier berganda, uji $F$ (simultan), uji t (parsial), dan koefisien determinasi (R2). Analisis regresi linier berganda yaitu untuk mengetahui pengaruh antara variabel independen terhadap variabel dependen dengan metode kuadrat kecil atau Ordinary Least Square (OLS) (Gujarati, 2007). Diketahui model fungsi produktivitas tenaga kerja sebagai berikut :

$$
Y=\beta_{0}+\beta_{1} X_{1}+\beta_{2} X_{2}+\beta_{3} X_{3}+\mu
$$

Dimana diketahui untuk variabel $\mathrm{Y}$ yaitu produktivitas tenaga kerja, variabel X1 yaitu pendidikan (Tahun), variabel X2 yaitu upah (Rupiah), variabel $\mathrm{X} 3$ yaitu umur (Tahun), $\beta 0$ yaitu konstanta, $\beta 1, \beta 2, \ldots, \beta 3 \quad$ yaitu koefisien regresi, dan $\mu$ yaitu variabel pengganggu.

\section{Hasil Uji Statistik}

\section{Uji F (Simultan)}

Uji statistik $F$ pada dasarnya untuk mengetahui apakah semua variabel independen yang dimasukkan dalam model mempunyai pengaruh secara bersama-sama terhadap variabel dependen. Pengujian setiap koefisien regresi bersama-sama dikatakan signifikan apabila nilai $\mathrm{F}$ hitung $>\mathrm{F}$ tabel, maka hipotesis nol $(\mathrm{H} 0)$ ditolak dan hipotetsis alternatif $(\mathrm{Ha})$ diterima (Gujarati, 2007). Diketahui model yang digunakan dalam Uji F sebagai berikut :

$$
\mathrm{F}=\frac{R^{2}-(k-2)}{\left(1-R^{2}\right)(N-k+1)}
$$

Dimana diketahui untuk $R^{2}$ yaitu koefisien determinasi, $\mathrm{N}$ yaitu jumlah observasi, dan k yaitu jumlah variabel.

\section{Uji t (Parsial)}

Uji signifikan $t$ pada dasarnya untuk mengetahui seberapa jauh pengaruh suatu variabel independen dalam menjelaskan variabel dependen. Uji $t$ digunakan untuk melihat signifikasi pengaruh variabel independen terhadap variabel dependen dengan menganggap variabel lain bersifat konstan. Pengujian setiap koefisien regresi dikatakan seignifikan bila nilai mutlak $\mathrm{t}$ hitung $>\mathrm{t}$ tabel, maka hipotesis nol $\left(\mathrm{H}_{0}\right)$ ditolak dan hipotesis alternatif $(\mathrm{Ha})$ diterima, artinya variabel independen mempengaruhi variabel 
dependen (Gujarati, 2007). Diketahui model yang digunakan dalam Uji t sebagai berikut :

$$
\mathrm{t}=\frac{\beta i}{\operatorname{Se}(\beta i)}
$$

Dimana diketahui untuk $\beta$ i yaitu koefisien regresi dan $\operatorname{Se}(\beta i)$ yaitu Standart Error koefisien regresi.

\section{Koefisien Determinasi $\left(\mathbf{R}^{2}\right)$}

Koefisien determinasi $\left(\mathrm{R}^{2}\right)$ pada dasarnya untuk mengukur seberapa jauh kemampuan model dalam menjelaskan variabel dependen. Nilai koefisien determinasi adalah antara 0 dan $1\left(0 \leq \mathrm{R}^{2} \leq 1\right)$. Nilai $\mathrm{R}^{2}$ yang kecil berarti kemampuan variabel-variabel independen dalam menjelaskan variabel dependen sangat terbatas. Nilai yang mendekati satu berarti variabel-variabel independen memberikan hampir semua informasi yang dibutuhkan untuk memprediksi variabel dependen (Ghozali, 2006).

\section{HASIL DAN PEMBAHASAN}

Jenis kelamin yang ada di industri pengolahan tembakau Kota Malang pada dasarnya untuk laki-laki masih memiliki peranan besar dibandingkan perempuan, kondisi ini berkaitan langsung dengan posisi laki-laki yang mayoritas menjadi tenaga kerja. Berikut data jenis kelamin karyawan industri pengolahan tembakau :

Tabel 1. Jenis Kelamin Tenaga Kerja PT Indonesian Tobacco Tbk. di Kota Malang 2019

\begin{tabular}{ccc}
\hline Jenis Kelamin & Jumlah & Prosentase (\%) \\
\hline Laki-laki & 26 & 70 \\
Perempuan & 11 & 30 \\
\hline Total & $\mathbf{3 7}$ & $\mathbf{1 0 0}$ \\
\hline
\end{tabular}

Sumber : data primer diolah, 2019

Berdasarkan tabel 1. diatas mengatakan bahwa karyawan laki-laki berperan lebih banyak pada industri pengolahan tembakau tersebut dibanding perempuan. Karena pada dasarnya industri tersebut lebih menbuthykan tenaga kerja yang memiliki kekuatan fisik yang kuat dan cepat.

Jumlah anggota keluarga responden merupakan tanggungan keluarga yang harus dihidupi. Berikut dapat dijelaskan standart tanggungan keluarga yang ditanggung oleh responden yaitu sebagai berikut :

Tabel 2. Jumlah Anggota Keluarga Tenaga Kerja PT Indonesian Tobacco Tbk. di Kota Malang 2019

\begin{tabular}{ccc}
\hline Jumlah Anggota Keluarga & Jumlah & Prosentase (\%) \\
\hline 2 & 6 & 16 \\
3 & 9 & 24 \\
4 & 11 & 30 \\
5 & 7 & 19 \\
6 & 4 & 11 \\
\hline
\end{tabular}


Produktivitas Tenaga Kerja Industri Pengolahan Tembakau Pada Pt Indonesian Tobacco Tbk. Kota Malang

Total

37

100

Sumber : data primer diolah, 2019

Berdasarkan tabel 2. diatas mengatakan bahwa adanya jumlah anggota keluarga, responden dapat memenuhi kebutuhan keluarga lebih banyak sesuai dengan jumlah keluarga yang dimiliki, sehingga untuk bisa memenuhi kebutuhan keluarga dengan baik maka kinerjanya harus ditingkatkan lebih banyak.

Bagian produksi pada PT Indonesian Tobacco Tbk. mempunyai beberapa sub bagian dan perincian jumlah responden pada tiap sub bagian. Berikut data Divisi kerja responde sebagai berikut :

Tabel 3. Divisi Tenaga Kerja PT Indonesian Tobacco Tbk. di Kota Malang 2019

\begin{tabular}{ccc}
\hline Divisi Kerja & Jumlah & Prosentase (\%) \\
\hline Packing & 14 & 38 \\
Rajang & 13 & 35 \\
Saos & 10 & 27 \\
\hline Total & $\mathbf{3 7}$ & $\mathbf{1 0 0}$ \\
\hline
\end{tabular}

Sumber : data primer diolah, 2019

Berdasarkan Tabel 3. diatas mengatakan bahwa dalam produksi terdapat beberapa bagian-bagian utama yang harus ada. Dari bagian-bagian diatas dapat meningkatkan atau menghasilkan produk yang diproduksi sesuai dengan kebutuhan, sehingga dari bagian-bagian tersebut membutuhkan karyawan yang lebih untuk bisa menghasilkan produk lebih banyak.

Produktivitas merupakan gambaran kemampuan pekerja dalam menghasilkan output pada PT Indonesian Tobacco Tbk. Berikut produktivitas diketahui sebagai berikut :

Tabel 4. Produktivitas Tenaga Kerja

\begin{tabular}{ccc}
\hline Produktivitas & Jumlah & Prosentase (\%) \\
\hline Rp $10,000-\operatorname{Rp~} 12,500$ & 24 & 65 \\
$\operatorname{Rp~} 12,501-\operatorname{Rp~} 15,000$ & 3 & 8 \\
$\operatorname{Rp~} 15,001-\operatorname{Rp~} 17,500$ & 10 & 27 \\
\hline Total & 37 & $\mathbf{1 0 0}$ \\
\hline
\end{tabular}

Sumber : data primer diolah, 2019

Berdasarkan Tabel 4. diatas mengatakan bahwa produktivitas tenaga kerja dihasilkan dari seberapa banyak jumlah produksi yang dihasilkan oleh para karyawan. Dengan semakin tingginya jumlah produksi maka semakin tinggi pula tingkat produktivitas masing-masing karyawan. Sehingga dapat dikatakan bahwa kemampuan para karyawan untuk menghasilkan jumlah produk dan peningkatan jumlah produksi menunjukkan semakin tingginya produktivitas kerja karyawan.

Pendidikan mempunyai pengaruh terhadap produktivitas tenaga kerja. Semakin tinggi pendidikan yang dimiliki seseorang maka akan meningkatkan ketrampilan dan upah yang diterima. Rendahnya tingkat pendidikan maka 
Produktivitas Tenaga Kerja Industri Pengolahan Tembakau Pada Pt Indonesian Tobacco Tbk. Kota Malang

dapat menyebabkan produktivitas tenaga kerja semakin rendah. Berikut data Tingkat Pendidikan Responden adalah sebagai berikut :

Tabel 5. Tingkat Pendidikan Tenaga Kerja PT Indonesian Tobacco Tbk. di Kota Malang 2019

\begin{tabular}{ccc}
\hline Tingkat Pendidikan (Tahun) & Jumlah & Prosentase (\%) \\
\hline SMA & 24 & 65 \\
SMP & 13 & 35 \\
\hline Total & $\mathbf{3 7}$ & $\mathbf{1 0 0}$ \\
\hline
\end{tabular}

Sumber : data primer diolah, 2019

Berdasarkan Tabel 5. diatas mengatakan pada dasarnya produktivitas tenaga kerja dibutuhkan tingkat pendidikan yang tinggi sehingga dengan adanya pendidikan yang tinggi maka produktivitas tersebut akan mengalami peningkatan dan juga sebaliknya jika pendidikan yang dimiliki rendah maka produktivitas tersebut akan rendah pula.

Upah merupakan imbalan atau gaji yang diperoleh oleh karyawan PT Indonesian Tobacco Tbk selama satu periode bekerja. Berdasarkan data yang diperoleh dari responden, berikut data upah yang diperoleh responden dalam satu periode bekerja sebagai berikut :

Tabel 6. Upah Tenaga Kerja PT Indonesian Tobacco Tbk. di Kota Malang 2019

\begin{tabular}{ccc}
\hline Upah & Jumlah & Prosentase (\%) \\
\hline Rp 1,000,000 - Rp 2,000,000 & 5 & 14 \\
$\operatorname{Rp~2,000,001~-~Rp~3,000,000~}$ & 22 & 59 \\
$\operatorname{Rp~3,000,001-Rp~4,000,000~}$ & 10 & 27 \\
\hline Total & $\mathbf{3 7}$ & $\mathbf{1 0 0}$
\end{tabular}

Sumber : data primer diolah, 2019

Berdasarkan Tabel 6. diatas mengatakan bahwa dengan adanya produk yang telah diproduksi maka akan menghasilkan produktivitas yang sesuai dengan seberapa banyak produk yang dihasilkan. Dari hasil tersebut maka akan diberikan suatu imbalan berupa upah yang akan diterima oleh karyawan. Sehingga upah yang diterima sesuai dengan kinerja yang dilakukan oleh masing-masing karyawan. Umur atau usia yaitu lama hidup seorang responden. Usia tersebut dapat dihitung ketika seseorang itu lahir sampai sekarang. Berikut data Umur responden sebagai berikut :

Tabel 7. Umur Responden

\begin{tabular}{ccc}
\hline Usia (Tahun) & Jumlah & Prosentase (\%) \\
\hline$<30$ & 3 & 8 \\
$31-35$ & 10 & 27 \\
$36-40$ & 15 & 41 \\
$41-45$ & 6 & 16
\end{tabular}




\begin{tabular}{ccc}
$46-50$ & 3 & 8 \\
\hline Total & 37 & $\mathbf{1 0 0}$ \\
\hline
\end{tabular}

Sumber : data primer diolah, 2019

Berdasarkan Tabel 7. diatas mengatakan bahwa pada dasarnya produktivitas tenaga kerja dibutuhkan umur yang layak. Umur memiliki kategori masing-masing sehingga tenaga kerja yang dimiliki sesuai dengan kategori. Untuk tenaga kerja diatas dibutuhkan umur yang produktif sehingga produktivitas yang dihasilkan baik dan sesuai dengan kinerja yang dilakukan.

Analisis regresi berganda dilakukan setelah semua data observasi terkumpul, kemudian diolah menggunakan perangkat lunak yang mendukung yaitu Eviews 9. Analisis data yang digunakan yaitu pengujian statistik. Berdasarkan dari data hasil penelitian tersebut maka dapat ditemukan hasil analisa regresi linier berganda sebagai berikut :

\section{Gambar 1. Hasil Analisis Linier Berganda}

Dependent Variable: LOG(PRODUKTIVITAS)

Method: Least Squares

Date: 08/11/19 Time: 07:13

Sample: 137

Included observations: 37

\begin{tabular}{lrlll}
\hline \hline \multicolumn{1}{c}{ Variable } & Coefficient & Std. Error & t-Statistic & Prob. \\
\hline \hline C & 4.596515 & 0.311248 & 14.76800 & 0.0000 \\
LOG(PENDIDIKAN) & 0.005208 & 0.013908 & 3.744750 & 0.0102 \\
$\quad$ LOG(UPAH) & 0.953186 & 0.021886 & 43.55136 & 0.0000 \\
$\quad$ LOG(UMUR) & 0.024181 & 0.017621 & 1.722533 & 0.0185 \\
\hline \hline R-squared & 0.982707 & Mean dependent var & 9.468529 \\
Adjusted R-squared & 0.981266 & S.D. dependent var & 0.116220 \\
S.E. of regression & 0.015908 & Akaike info criterion & -5.349408 \\
Sum squared resid & 0.009110 & Schwarz criterion & -5.180520 \\
Log likelihood & 110.9882 & Hannan-Quinn criter. & -5.288343 \\
F-statistic & 681.9074 & Durbin-Watson stat & 2.082356 \\
Prob(F-statistic) & 0.000000 & & & \\
\hline \hline
\end{tabular}

Sumber : data primer diolah, 2019

Untuk pengujian statistik dimaksudkan guna mengetahui pengaruh suatu variabel bebas terhadap variabel terikat. Dalam hal ini pengujian dilakukan untuk mengetahui apakah hipotesis yang telah digunakan sesuai dengan kenyataan.

\section{Uji F (Pengujian secara Simultan)}

Dari hasil analisis linier berganda diperoleh Ftabel $(2,87)>$ Fhitung $(681,9074)$ sehingga dari perhitungan diatas dapat diketahui bahwa H_o ditolak dan $\mathrm{H}_{-} 1$ diterima. Dengan demikian menunjukkan bahwa variable Tingkat Pendidikan, Umur, dan Upah secara simultan memiliki pengaruh yang signifikan terhadap Produktivitas Tenaga Kerja Indutri Pengolahan Tembakau di Kota Malang. 


\section{Uji t (Pengujian secara Parsial)}

Untuk mengetahui pengaruh signifikan variabel tingkat pendidikan, upah, dan umur terhadap produktivitas tenaga kerja indutri pengolahan tembakau di Kota Malang digunakan uji t (t-test) untuk membandingkan dengan nilai $t$ hitung dengan $t$ tabel dengan confindent interval sebesar 95\% $(\alpha=5 \%)$. Diketahui perbandingan hasil uji t sebagai berikut :

Tabel 8. Hasil Uji t Perbandingan Antara Nilai $t_{\text {hitung }}$ dengan $t_{\text {tabel }}$

\begin{tabular}{cccc}
\hline Variabel & $t_{\text {hitung }}$ & $\mathrm{t}_{\text {tabel }}$ & Keterangan \\
\hline LOG(PENDIDIKAN) & 3,744750 & 1,68830 & Signifikan \\
LOG(UPAH) & 43,55136 & 1,68830 & Signifikan \\
LOG(UMUR) & 1,722533 & 1,68830 & Signifikan \\
\hline
\end{tabular}

Sumber : data primer diolah, 2019

Berdasarkan Tabel 8. diatas menunjukkan bahwa dari ketiga variabel tersebut yaitu tingkat pendidikan, upah, dan umur berpengaruh signifikan terhadap produktivitas tenaga kerja indutri pengolahan tembakau di Kota Malang. Secara uji parsial atau uji t dapat dijelaskan sebagai berikut :

Variabel Tingkat Pendidikan Terhadap Produktivitas Tenaga Kerja

Hasil analisis menunjukkan bahwa nilai t_hitung $(3,744750)>$ t_tabel $(1,68830)$ sehingga berdasarkan hasil tersebut dapat menunjukkan bahwa variable tingkat pendidikan berpengaruh positif dan signifikan terhadap produktivitas tenaga kerja industri pengolahan tembakau di Kota Malang.

\section{Variabel Upah Terhadap Produktivitas Tenaga Kerja}

Hasil analisis menunjukkan bahwa nilai t_hitung $(43,55136)>\mathrm{t}$ tabel $(1,68830)$ sehingga berdasarkan hasil tersebut dapat menunjukkan bahwa variable upah berpengaruh positif dan signifikan terhadap produktivitas tenaga kerja indutri pengolahan tembakau di Kota Malang.

\section{Variabel Umur Terhadap Produktivitas Tenaga Kerja}

Hasil analisis menunjukkan bahwa nilai t_hitung $(1,722533)>\mathrm{t}$ ttabel $(1,68830)$ sehingga berdasarkan hasil tersebut dapat menunjukkan bahwa variable umur berpengaruh positif dan signifikan terhadap produktivitas tenaga kerja indutri pengolahan tembakau di Kota Malang.

Analisis regresi linier berganda guna untuk mengetahui pengaruh variabel tingkat pendidikan, upah, dan umur terhadap variabel produktivitas tenaga kerja. Berdasarkan hasil analisa regresi linier pada Gambar 1. maka dapat dirumuskan persamaan regresi linier berganda sebagai berikut :

$\mathrm{Y}=4,596+0,005 \log \mathrm{X} 1+0,953 \log \mathrm{X} 2+0,024 \log \mathrm{X} 3+\mathrm{e}$

Dari model persamaan (4) menjelaskan bahwa variabel pendidikan (X1), variabel upah (X2), dan variabel umur (X3) berpengaruh terhadap produktivitas tenaga kerja (Y). 
Penelitian ini menunjukkan hasil yang sesuai dengan yang diharapkan. Berikut merupakan penjelasan kemaknaan dari variabel independen terhadap variabel dependen adalah :

\section{Pengaruh Variabel Tingkat Pendidikan Terhadap Produktivitas Tenaga Kerja}

Berdasarkan hasil uji statistik variabel tingkat pendidikan memiliki pengaruh positif dan signifikan terhadap variabel produktivitas tenaga kerja. Koefisien regresi pendidikan yaitu sebesar 0,005 dengan tanda positif. Hal ini berarti apabila variabel tingkat pendidikan naik sebesar 1\%, maka tingkat pendidikan akan bertambah sebesar $0,5 \%$. Dengan asumsi variabel upah dan umur dianggap konstan.

Hasil ini sesuai dengan penelitian yang dilakukan oleh Rohani (2017) yang menyatakan bahwa tingkat pendidikan apabila mengalami kenaikan atau semakin tinggi tingkat pendidikan seseorang maka akan meningkat tingkat produktivitas tenaga kerja dan sebaliknya. Selain itu sama halnya dengan penelitian yang dilakukan oleh Kurniawan (2010) yang menyatakan bahwa pada umumnya orang yang mempunyai pendidikan formal maupun informal yang lebih tinggi akan mempunyai wawasan yang lebih luas. Tingginya kesadaran akan pentingnya produktivitas, akan mendorong tenaga kerja yang bersangkutan melakukan tindakan yang produktif. Hal ini sesuai dengan teori yang disampaikan oleh Simanjuntak (2001) bahwa semakin tinggi tingkat pendidikan seseorang maka semakin tinggi pula tingkat produktivitas ataupun kinerja tenaga kerja tersebut. Dari hasil ini mengatakan bahwa tingkat pendidikan berpengaruh positif terhadap produktivitas, karena orang yang berpendidikan lebih tinggi memiliki pengetahuan yang lebih untuk bisa mendorong dan meningkatkan kinerjanya.

\section{Pengaruh Variabel Upah Terhadap Produktivitas Tenaga Kerja}

Berdasarkan hasil uji statistik variabel upah memiliki pengaruh positif dan signifikan terhadap variabel produktivtas tenaga kerja. Koefisien regresi upah yaitu sebesar 0,953 dengan tanda positif. Hal ini apabila variabel upah naik sebesar $1 \%$, maka upah akan bertambah sebesar 95,3\%. Dengan asumsi variabel tingkat pendidikan dan umur dianggap konstan.

Hasil ini sesuai dengan penelitian yang dilakukan oleh Adhadika (2014) yang mengatakan bahwa tenaga kerja yang mendapatkan upah lebih tinggi akan memiliki produktivitas tenaga kerja yang lebih besar. Selain itu sama halnya dengan penelitian yang dilakukan oleh Setiadi (2009) yang mengatakan bahwa besar kecilnya upah yang diberikan perusahaan kepada para pekerjanya akan mempengaruhi tinggi rendahnya tingkat produktivitas kerja karyawan. Hal ini sesuai dengan teori yang disampaikan oleh Sumarlin et al (2010) bahwa produktivitas tenaga kerja tergantung pada tingkat upah yang diterima. Tenaga kerja yang mendapatkan upah tinggi maka dapat memenuhi kebutuhan hidup dengan mengkonsumsi makanan yang bergizi dan badan menjadi sehat, dengan demikian dapat mengalokasikan waktu bekerjanya lebih tenang sehingga produktivitas kerja dapat ditingkatkan. Dari hasil ini mengatakan bahwa tingkat upah berpengaruh positif terhadap 
produktivitas, karena jika seorang pekerja merasa nyaman dengan upah yang diterima maka produktivitasnya dalam bekerja diharapkan akan meningkat.

\section{Pengaruh Variabel Umur Terhadap Produktivitas Tenaga Kerja}

Berdasarkan hasil uji statistik variabel umur memiliki pengaruh positif dan signifikan terhadap variabel produktivtas tenaga kerja. Koefisien regresi umur yaitu sebesar 0,024 dengan tanda positif. Hal ini apabila variabel umur naik sebesar 1\%, maka umur akan bertambah sebesar 2,4. Dengan asumsi variabel tingkat pendidikan dan upah dianggap konstan.

Hasil ini sesuai dengan penelitian yang dilakukan oleh Hasanah (2011) yang mengatakan bahwa umur yang lebih muda menunjukkan fisik yang kuat sehingga mampu bekerja lebih cepat dan pada akhirnya akan mampu mengahasilkan output yang meningkat dan sebaliknya. Selain itu sama halnya dengan penelitian yang dilakukan oleh Amron (2009) yang menyatakan bahwa umur tenaga kerja cukup menentukan keberhasilan dalam melakukan suatu pekerjaan, baik sifatnya fisik maupun non fisik. Pada umumnya, tenaga kerja yang berumur tua mempunyai tenaga fisik yang lemah dan terbatas, sebaliknya tenaga kerja yang berumur muda mempunyai kemampuan fisik yang kuat. Dan hal ini sesuai juga dengan penelitian yang dilakukan oleh Herawati (2013) yang menyatakan bahwa umur yang produktif memiliki batas usia tertentu, dimana semakin bertambah umur semakin produktif karena dianggap memiliki pengalaman kerja yang lebih banyak dibanding yang masih muda, kecuali tenaga kerja yang memasuki pangsa pensiun. Hal ini sesuai dengan teori yang disampaikan oleh Mahendra (2014) bahwa usia yang masih dalam masa produktif biasanya mempunyai tingkat produktivitas lebih tinggi dibandingkan dengan tenaga kerja yang sudah berusia tua sehingga fisik yang dimiliki menjadi lemah dan terbatas. Dari hasil ini mengatakan bahwa umur memiliki pengaruh positif terhadap peningkatan produktivitas tenaga kerja.

\section{KESIMPULAN}

Berdasarkan hasil analisis yang telah dilakukan dapat disimpulkan bahwa untuk pengaruh variabel tingkat pendidikan terhadap produktivitas tenaga kerja berdasarkan hasil uji statistik variabel tingkat pendidikan memiliki pengaruh positif dan signifikan terhadap variabel produktivtas tenaga kerja Kemudian untuk pengaruh variabel upah terhadap produktivitas tenaga kerja berdasarkan hasil uji statistik variabel upah memiliki pengaruh positif dan signifikan terhadap variabel produktivitas tenaga kerja. Dan untuk pengaruh variabel umur terhadap produktivitas tenaga kerja berdasarkan hasil uji statistik variabel umur memiliki pengaruh positif dan signifikan terhadap variabel produktivtas tenaga kerja.

Penelitian ini memiliki beberapa keterbatasan masalah yang hanya menjelaskan produktivias tenaga kerja pada industri pengolahan tembakau PT Indonesian Tobacco Tbk. Kota Malang saja, padahal masih banyak produktivitas tenaga kerja pada perusahaan lain. Dan penelitian ini hanya 
membahas satu objek perusahaan saja, sebab di Kota Malang hanya ada satu perusahaan industri pengolahan tembakau.

\section{DAFTAR PUSTAKA}

Adhadika, T., \& Pujiyono, A. (2013). Analisis Faktor-Faktor Yang Mempengaruhi Produktivitas Tenaga Kerja Industri Pengolahan Di Kota Semarang. Diponegoro Journal Of Economics, V(3), 1-13.

Amron, \& Taufik, I. (2009). Analisis Faktor-Faktor Yang Berpengaruh Terhadap Produktivitas Tenaga Kerja Pada Outlet Telekomunikasi Seluler Kota Makassar. Jurnal Sekolah Tinggi Ilmu Ekonomi Indonesia.

Badan Pusat Statistik. (2018). Kecamatan Blimbing Dalam Angka 2018. Retrieved 24 Maret 2019, from https://malangkota.bps.go.id/publikasi.html.

Badan Pusat Statistik. (2018). Kota Malang Dalam Angka 2018. Retrieved 24 Maret 2019, from https://malangkota.bps.go.id/publication/2018/08/16/c99aac182fb1c32d2b e35e49/kota-malang-dalam-angka-2018.html.

Bolehmerokok.com. (2018). KNPK minta Pemerintah perhatikan nasib industri kecil pengolahan tembakau. Retrieved 14 Maret 2019, from https://bolehmerokok.com/2018/02/knpk-minta-pemerintah-perhatikannasib-industri-kecil-pengolahan-tembakau/.

Bolehmerokok. (2018). Nasib Pada Industri Kecil Pengolahan Tembakau. Retrieved 14 Maret 2019, from https://bolehmerokok.com /2018/02/ nasib-industri-kecil-pengolahan- tembakau/.

Djunaedi, M. H. (2009). Analisis Proyeksi Kesempatan Kerja dan Produktivitas Tenaga Kerja di Kabupaten Lombok Barat 2010-2025. Jurnal Ekonomi Pembangunan, V(7), 7-12.

Herawati, N. (2013). Analisis Pengaruh Pendidikan, Upah, Pengalaman Kerja, Jenis Kelamin Dan Umur Terhadap Produktivitas Tenaga Kerja Industri Shuttlecock Kota Tegal. Universitas Diponegoro Semarang.

Hidayatullah, M. N. (2013). Pengaruh Modal dan Tenaga Kerja Usaha Pengrajin Batik Tulis Klasik Terhadap Tingkat Produksi (Studi Pada Industri Kecil Menengah "IKM" Batik Tulis Klasik di Desa Margorejo, Kecamatan Kerek, Kabupaten Tuban). Jurnal Ekonomi Pembangunan, V(11), 4-11.

Indonesiantobacco.com. (2019). Riwayat PT Indonesian Tobacco Tbk. Retrieved 3 Juli 2019, from https://www.indonesiantobacco.com/.

Kurniawan, G. (2010). Faktor-Faktor Yang Mempengaruhi Produktivitas Tenaga Kerja Pada PT. Kalimantan Steel (PT. Kalisco) Pontianak. Jurnal Ekonomi, V(12), 41-58.

Mahendra, A. D. (2014). Analisis Pengaruh Pendidikan, Upah, Jenis Kelamin, Usia dan Pengalaman Kerja Terhadap Produktivitas Tenaga Kerja 
(Studi di Industri Kecil Tempe di Kota Semarang). Doctoral Dissertation. Universitas Diponegoro Semarang.

Maria, S. (2012). Faktor Pendorong Peningkatan Produktivitas Tenaga Kerja Wanita Sektor Industri, Perdagangan dan Jasa di Kalimantan Timur. Universitas Mulawarman.

Prasetyo, A. (2014). Analisis Faktor-Faktor Yang Mempengaruhi Produktivitas Pada Tenaga Kerja (Studi Kasus CV. Agro Bintang Terang Desa Trimo Kecamatan Gedangan Turen Kabupaten Malang). Jurnal Ilmiah.

Putri, Y. A. K. D. (2017). Analisis Pengaruh Tingkat Kesehatan, Tingkat Pendidikan, dan Upah Terhadap Produktivitas Tenaga Kerja di Indonesia. JIEP, V(17).

Rahman, A. J. (2016). Pengaruh Investasi, Pengeluaran Pemerintah dan Tenaga Kerja Terhadap PDRB Kabupaten/Kota Di Propinsi Banten Tahun 2010-2014. Jurnal Ekonomi Pembangunan, V(14), 6-9.

Rohani, I. (2017). Analisis Produktivitas Tenaga Kerja Pada Dwi Putra Perkasa Garment Di Kota Malang. Skripsi. Malang: Universitas Muhammadiyah Malang.

Sasmitha, N. P. R \& Ayuningsasi, A.A. K. (2017). Faktor-Faktor Yang Mempengaruhi Pendapatan Pengrajin Pada Industri Kerajinan Bambu Di Desa Belega Kabupaten Gianyar. E-Jurnal EP Unud, V(6), 64-84.

Setiadi. (2009). Pengaruh Upah dan Jaminan Sosial Terhadap Produktivitas Kerja Karyawan di PT Semarang Makmur Semarang. Tesis. Magister Kenotariatan Undip.

Sulistyono, S. W. (2011). Mobilitas Tenaga Kerja dari Sektor Pertanian ke Sektor Non Pertanian di Kecamatan Lawang Kabupaten Malang. Jurnal Ekonomi Pembangunan, V(9), 5-21.

Sumarlin, Syarief, Ritonga, Sirojuzalim. (2010). Analisis Hubungan Tingkat Upah Tinggi Terhadap Produktivitas di Indonesia. Jurnal Mepa Ekonomi USU.

Tambunan, V. (2012). Analisis Pengaruh Pendidikan, Upah, Insentif, Jaminan Sosial, dan Pengalaman Kerja Terhadap Produktivitas Tenaga Kerja di Kota Semarang ( Studi Kasus Kecamatan Banyumanik dan Kecamatan Gunung pati). Skripsi. Universitas Diponegoro Semarang.

Thinkway.id. (2019). Industri Pengolahan Tembakau Kota Malang. Retrieved 14 Maret 2019, from http://thinkway.id/08/02/2019 /00/31/kota-malang-punya-industri-pengolah-tembakau-terbanyak-di-jawatimur/.

Tomasowa, O. L. E. (2011). Analisis Penyerapan Tenaga Kerja di Kota Kupang Propinsi Nusa Tenggara Timur 2005-2010. Jurnal Ekonomi Pembangunan, V(9), 8-14.

Wignjosoebroto, S. (2003). Ergonomi Studi Gerak dan Waktu: Teknik Analisis Untuk Meningkatkan Produktivitas Kerja. PT. Gunawidya Jakarta. 